\title{
THE EFFECTS OF EMPLOYMENT AND FINANCIAL EMPOWERMENT OF WOMEN ON DOMESTIC VIOLENCE: THE CASE OF TURKEY
}

\author{
Yahya ALGÜL* \\ İkram Yusuf YARBAŞI**
}

\begin{abstract}
As one of the fastest developing countries in the world, Turkey has been suffering from domestic violence significantly in recent decades and it has been one of the hottest topics discussed both in public and in the national media. On the other hand, it is interesting that according to United Nations Turkey is one of the leading countries in the MENA regarding the fight against domestic violence and supporting women's legal rights in general. However, beyond the legal rights and state support to women, together with other socioeconomic factors, employment status and financial empowerment of women may be linked to sexual and physical violence against women. In this study, it is aimed to investigate this potential relationship by using the "Research on Domestic Violence Against Women in Turkey" survey data conducted by the Turkish Statistical Institute in 2014. The multinomial probit model was used to modeling the effects of employment and financial empowerment on violence against women. According to estimations results, women who have a job may less likely to experience some types of domestic violence.
\end{abstract}

Keywords: Violence Against Women, Women Employment, Women Financial Empowerment, Multinomial Probit Model.

\footnotetext{
* Dr. Öğretim Üyesi, Erzurum Teknik Üniversitesi, İktisadi ve İdari Bilimler Fakültesi İktisat Bölümü, yahya.algul@erzurum.edu.tr, https://orcid.org/0000-0003-3480-9871

${ }^{* *}$ Dr. Öğretim Üyesi, Erzurum Teknik Üniversitesi, İktisadi ve İdari Bilimler Fakültesi Ekonometri Bölümü, ikram.yarbasi@erzurum.edu.tr, https://orcid.org/0000-0003-4689-5121
} 


\title{
KADINLARIN İSTIHDAMININ VE MALİ GÜÇLENMESINIIN AİLE ICÇI ŞIDDETE ETKILERİ: TÜRKIYYE ÖRNEĞİ
}

\begin{abstract}
ÖZ
Dünyanın en hızlı gelişen ülkelerinden biri olan Türkiye'de, kadınlar son yıllarda aile içi şiddete önemli ölçüde maruz kalmakta ve bu husus hem kamuoyunda hem de ulusal medyada tartışılan en önemli konulardan biri durumunda yer almaktadır. Öte yandan, Birleşmiş Milletler'e göre Türkiye'nin aile içi şiddetle mücadele ve genel olarak kadınların yasal haklarının desteklenmesi konusunda MENA'nın önde gelen ülkelerinden biri olması ilginç bir husustur. Diğer yandan, kadınlara yönelik yasal hakların ve devlet desteğinin ötesinde, kadınların istihdam durumu ve kadınların mali olarak güçlendirilmesi gibi faktörler de, diğer sosyoekonomik faktörlerle birlikte, kadına yönelik cinsel ve fiziksel şiddetle bağlantılı olabilir. Bu çalışmada, Türkiye İstatistik Kurumu'nun 2014 yılında gerçekleştirdiği “Türkiye'de Kadına Yönelik Aile İçi Şiddet Araştırması" anket verileri kullanılarak, bu potansiyel ilişkinin araştırılması amaçlanmıştır. İstihdam ve mali güçlenmenin kadına yönelik şiddet üzerindeki etkilerini modellemek için çok terimli probit modeli kullanılmıştır. Tahmin sonuçlarına göre, bir işi olan kadınların aile içi şiddetin bazı türlerine maruz kalma olasıllı̆ı daha düşük bulunmuştur.
\end{abstract}

Anahtar Kavramlar: Kadına Yönelik Şiddet, Kadın İstihdamı, Aile içi Şiddet, Çok Terimli Probit Modeli.

\section{INTRODUCTION}

Intimate partner violence (IPV) is one of the most significant and complex social problems across regional, social and cultural frontiers. Regardless of a country's level of development, women are susceptible to abuse, oppression, and other types of demeaning violence from men in all societies where cultural norms, tradition and the legal system endorse women's subordination to men (Wahed and Bhuiya, 2007).

According to World Health Organization (WHO), IPV is defined as the "behaviour within an intimate relationship that causes physical, sexual or psychological harm, including acts of physical aggression, sexual coercion, psychological abuse and controlling behaviours"(World Health Organization [WHO]). This definition applies to abuse by both current and former spouses and partners.

Until the 1970s, IPV had been considered as a private matter of households in which external factors needed not to step in and poverty or economic dependency of women on men also deteriorated the problem (Gul, 2013). While IPV isn't a new phenomenon, what is new is the increasing recognition that it is not an isolated event, which affects nearly one-third of women worldwide, and this form of behavior violates the rights of women, limits their participation in society, and injures their health and well-being (WHO, 2013). 
$38 \%$ of all murders of women in the world are committed by intimate partners; and IPV causes many health problems such as; women who experienced IPV are $16 \%$ more likely to have a low-birth-weight baby, approximately twice as likely to have an abortion, nearly twice as likely to experience depression, and, in some countries, are 1.5 times more likely to acquire HIV, compared to women haven't been exposed to IPV (WHO, 2013). According to the Centers for Disease Control, the approximate costs of IPV related to medical care and productivity loss is $\$ 5.8$ billion annually only in U.S.A. (Aizer, 2010).

Reviewing literature shows that most of the studies concerning IPV were conducted in the case of developed countries, North America with $41 \%$, followed by Europe with 20\%, and Asia with 16\%, while studies conducted for the case of African and the Middle East countries make up only $11 \%$ and $5 \%$ of the total number of studies respectively (Alhabib, Nur and Jones, 2010). However, both meaning and determinative factors of violence may vary from culture to culture and from country to country. Therefore, developing countries' dynamics of IPV may considerably vary from those developed ones.

As one of the fastest developing countries in the world, Turkey has been suffering from domestic violence significantly in recent decades and it has been one of the hottest topics discussed both in public and in the national media. According to the Ministry of Family and Social Policies report of Turkey (Ministry of Family and Social Policies [MFSP], 2014), in Turkey, the proportion of ever-married women who declared having been exposed to physical, sexual, and emotional violence is $36 \%, 12 \%$, and $44 \%$ respectively. Moreover, divorced or separated women are found to be more likely to be victimized by their partners, as $75 \%$ of ever abused women are found to be divorced or separated women (MFSP, 2014).

According to different studies conducted in Turkey, $15 \%-65 \%$ of women are exposed to physical violence (Alan, Y1lmaz, Filiz and Arioz 2016; Kocacik and Caglayandereli, 2009; Ozyurt and Deveci, 2010; Sahin and Dundar, 2017), 52\%-66\% to verbal violence (Alan et al., 2016; Kocacik and Caglayandereli, 2009; Ozyurt and Deveci, 2010), and 6.3\%-15\% to sexual violence (Alan et al., 2016; Kocacik and Caglayandereli, 2009; Ozyurt and Deveci, 2010; Sahin and Dundar, 2017). Moreover, 24\%-55\% of the women reported the type of violence committed by their husbands or ex-husbands as psychological violence and $13.5 \%-19.3 \%$ as economic violence (Dikmen and Munevver 2020).

Additionally, femicide is another severe type of IPV which is endemic in Turkey. The Ministry of Justice stated that the rate of murdered women in Turkey increased by $1,400 \%$ between 2002 and 2009 and after this report, the Turkish government stopped releasing femicide statistics, but according to 
Independent Communication Network statistics compiled from national and local newspapers, news websites, and agencies, in Turkey during 2016, men killed at least 261 women, raped 75, harassed 119, injured 348, and sexually abused 417 girls (Talhaoglu and Baki, as cited in, Kerman and Betrus 2018). According to independent agencies, femicide in Turkey increased from 66 in 2008 to 474 in 2019, annually (Muftuler-Bac and Muftuler, 2020).

Beyond the reported statistics, it may also be speculated that actual violence cases may be higher than the reported. Because, IPV is viewed as a private matter and victimized women are left alone in the family and women oftentimes do not have the necessary understanding, awareness, courage, and/or necessary resources to reap the benefits of their legal rights (Gul 2013). Moreover, women in Turkey tend to think that IPV is an ordinary situation seen in all marriages and they do not seek solutions that cause women to keep suffering from high levels of IPV ranging from obvious methods to more subtle methods (Gul, 2013).

On the other hand, it is interesting that according to United Nations Turkey is one of the leading countries in the MENA regarding the fight against IPV and supporting women's legal rights in general (Ergöçmen, Kaptanoğlu and Jansen, 2013). Upon the women's movements in the 1980s, the first law about women's rights enacted in the 1990s together with the establishment of women's shelters which is followed by the "Protection of Family Law" against IPV in 1998 (Ergöçmen, et. al, 2013). Later on, numerous regulations were implemented to protect women's rights and prevent IPV in Turkey.

Moreover, Istanbul Convention which is the most comprehensive international cooperation against domestic violence was opened to signature in Istanbul, Turkey and it was the first country that ratified the convention ${ }^{1}$. Followed the convention Turkey enacted the "Protection of the Family and Prevention of Violence Against Women Law" which was brought a new set of very sound institutions and regulations to prevent domestic violence. However, it should be stressed that modern laws and regulations are not sufficient to guarantee success in practice, as women in Turkey still has been deeply affected by IPV.

Considering the complexity of the problem that is embedded in all parties of society and affects different aspects of life, intimate partner violence has drawn the attention of researchers and policymakers in a variety of fields, from judicial to medical disciplines (Castro, Peek-Asa and Ruiz, 2003). In comparison to the number of studies conducted from the perspective of sociology, criminology, juridical disciplines, medical and other disciplines, the number of studies conducted from an economics perspective is much smaller.

\footnotetext{
${ }^{1}$ For some reason Turkey is resignated from Istanbul Convention on 19.03.2021( Official Gazette, 2021)
} 
But intimate partner violence may have economic dynamics connected to the familial budgets, women's financial independence, and other psychological factors that affect both males and females. All of those economic factors are closely related to the employment status of both men and women.

According to the Turkish Statistical Institute's January 2021 Labor Force Statistics, female and male unemployment rates were $14.1 \%$ and $11.4 \%$ respectively and labor force participation rates were $32 \%$ and $68.2 \%$, for women and men, respectively (TSI, 2021). The women's labor force participation rates are very low compared to the rest of the world. This is, in some part, due to the prevelance of informal employment among women in Turkey and in some part due to other socioeconomic factors. Since women with low educational attachment generally have a very low chance in the labor market compared to men. This situation, when combined with the negative perception of female employment in society, women pushed out of formal employment opportunities toward low-paid and laborious informal employment, such as familial agricultural jobs (Varisli, 2021).

Considering the relatively high male unemployment and even higher female unemployment rates together with the very low labor force participation of women in Turkey, the effects of unemployment and financial condition of couples on the IPV is investigated through Multinomial Probit Models. However, it should be noted that due to data limitations only sexual violence and physical violence are taken as a proxy for IPV and psychological violence couldn't be investigated.

After this introduction section, in section two, the literature is reviewed. In section three methodology and datasets used are detailed. Section four summarizes findings and finally, in section five discussion and conclusion are covered.

\section{LITERATURE REVIEW}

The causal relationship between employment or financial conditions of couples and intimate partner violence is mainly reviewed from two very distinct perspectives. According to the first line of thought, household bargaining theory; as women's wage increases their bargaining power increases and, therefore reduces the possibility of violence as their option to leave a harmful relationship increases (Aizer, 2010). The intuition for this is, when a man with a violent tendency has a high unemployment risk, he might hide his true nature by behaving as a non-violent man as his partner, given his low expected future income, might leave him due to his violent nature (Anderberg, Rainer, Wadsworth and Wilson 2016). On the other hand, when a female is unemployed and has no income, she may have less financial independence to leave her partner in the case of violence. Therefore, while male unemployment is expected to decrease domestic violence, female unemployment is expected to increase 
domestic violence. Accordingly, for battered women employment may be an important tool to protect themselves from intimate partner violence.

However, especially in some societies according to their social norms, institutions, or religious principles, the bread earner role is assigned to men principally and working women undermine the bread-earner role of men (Sumantra, 2019). Therefore according to male backlash theory which is the second theory in the literature that investigates the causal relationship between intimate partner violence and unemployment; as women's financial independence and bargaining power increase men may use violence as a tool to reinstate their power and control women independence and risk of abandonment (Guarnieri and Rainer, 2018).

The existing evidence for advanced nations mostly supports the predictions of household bargaining theory (Guarnieri and Rainer, 2018). For example, Bowlus and Seitz (2006) investigated the relationship between domestic violence, employment, and divorce with a survey inclusive of 12.300 women participants aged 18 and above in all provinces of Canada. According to their estimate, women's employment decisions have a causal effect on violence, as employed females are less likely to be abused by their partners. Moreover, a study conducted by Anderberg et al. (2016) by consolidating data from the British Crime Survey with labor market data from the UK's Annual Population Survey concluded that; a rise in men unemployment reduces the chance of intimate partner violence, while a rise in women unemployment increases intimate partner violence.

Another study done at Hackney, London UK with 1207 primary care participants, concluded that divorced or separated and unemployed females under 45 were at a bigger risk of current physical violence from a current or former partner (Richardson and et. al., 2002). In a different study (Aizer, 2010) where female hospitalization in California is used as a new measure of abuse, the relationship between the gender wage gap and violence is investigated. According to estimation results, the decline in the wage gap between genders which is witnessed over the past 13 years, may explain the nine percent of reduction in intimate partner violence.

For the case of developing countries too, similar findings were observed which supports household bargaining theory. In the study done for the case of India by Gaikwad and Rao(2014) 548 married women from northwest Mumbai were interviewed to analyze the socio-economic and demographic dynamics of IPV. According to percentages analysis and chi-square test results, nonworking housewives are abused more than working wives. In another study, Indian national family health survey data of the year 2005 was utilized to analyze the socio-economic predictors of IPV against spouses and children with logistic regression technique (Bhattacharya and Bhattacharya, 2014). Based on the estimation results women's financial independence is found to be associated with 
less intimate partner violence. Jeyaseelan and his colleagues (2007) found similar estimation results that support household bargaining theory in the case of India. According to Gage(2005), male unemployment is a risk factor, while women's economic independence is found to be a protective buffer against IPV in Haiti.

Nevertheless, in some country cases, some evidence is founded in favor of male backlash theory. Based on the multi-country study of Kishor and Johnson (2004) in Iran, Nicaragua, Columbia, the Dominican Republic and India income earning women may have a higher risk of physical, sexual, or both types of IPV in comparison to women not working. According to a study conducted in rural Bangladesh with a population-based survey of 2,702 participants by Naved and Persson (2005) for women earning an income increases the risk of abuse. In the case of Albania based on the study of Burazeri and his colleagues (2005), which is done with 1039 married women aged between 25 and 65 living in Tirana, women with a white-collar job are at a higher risk of physical violence in comparison to non-working housewives. Using a randomized control trial in rural Ethiopia, Hjort and Villanger found that when a woman gets employed physical violence increases by $13 \%$, while emotional violence increases by $34 \%$ (Hjort and Villanger, as cited in, Paul, 2016).

Another study was conducted by Brownridge and Halli (2002) to analyze the prevalence and causes of IPV among immigrant women in Canada. Their findings show that immigrant women from developing countries have the highest risk of abuse and women employment is associated with a higher risk of IPV.

Heath (2014) using data from Bangladesh, documented a positive correlation between employment and IPV, but only among females with low education or marriage at a young age. This suggests that females with low bargaining power may encounter a higher risk of IPV upon entering the labor force as their partners' search for ways to reinstate their high bargaining power. In this way, Heath's study seems to have some support to both the household bargaining and male backlash theory.

On the other hand, beyond male backlash and household bargaining theory, some studies found no relation between employment and IPV. According to the multi-country work of Kishor and Johnson (2004) in Cambodia, Haiti, Zambia, and the Philippines, there was no significant association between employment and IPV. A study done at Lesotho based on a random household survey of 939 sexually active women aged $18-35$, current employment is not linked to the findings of both of their models (Brown, Thurman, Bloem and Kendall, 2006). For the case of Sub Saharan country of Rwanda too, based on the estimation results, the employment status of women is not a relevant determinant of domestic violence (Mattina, 2017). Chin, Song and Stamey (2017) investigated the effect of women's employment on IPV in urban India, 
using a Bayesian misclassification model combined with propensity score regression estimation, and found no supporting evidence that the employment condition of women affects the odds of physical violence.

Male backlash and household bargaining theories concern the bilateral financial power relations among men and women. However, combined economic conditions of partners, in another word, poverty in households also may be an important determinative factor in IPV. Findings in literature, however, are mixed. Ogland, Bartkowski, and Ogland (2014) found that Ugandan females with larger household wealth were at a lower risk of physical violence while finding for emotional violence doesn't support the argument. Yount(2005) found that household wealth is negatively associated with physical violence in Minya, Egypt. Bamiwuye and Odimegwu (2014) in their investigation for sub-Saharan African countries found that in rich households of Zambia and Mozambique domestic violence risk is higher than in middle and low-income households. However, For Zimbabwe and Kenya women in poor households are more likely to become the victim of IPV, while in Nigeria and Cameroun, women from middle-income households are more likely to experience violence than those from poor and rich households (Bamiwuye and Odimegwu, 2014).

Apart from the theories explained, another theory that supports female employment from a non-economic perspective is exposure reduction theory. Developed by criminologists, exposure reduction theory assumes that rising labor force participation of females may decrease IPV because as women spend more time working outside spend less time with their violent spouse (Aizer, 2010). Evidence for exposure theory, however, is mixed. According to Aizer(2010) reduction in IPV as a result of the falling wage gap between partners occurs during the weekend, which is inconsistent with the exposure reduction hypothesis. Dugan and others (2003) investigated the factors that affect intimate partner homicide from the exposure reduction perspective in the United States. According to predictions while findings are mixed, most of the findings support the exposure reduction theory. Chin (2012) found that female labor force participation may reduce the likelihood of physical IPV in India. But this result is found not to be an outcome of household bargaining theory, rather it is found that exposure reduction is the key element in reducing violence (Chin, 2012).

As it is the case for the international literature review, mixed results regarding the relationship between employment and domestic violence can be seen in the studies conducted specifically for the case of Turkey too. Kocacik, Kutlar and Ersancar (2007) investigated the dynamics of IPV in four Turkish cities (Kırklareli, Sivas, Adiyaman, and Denizli) and found that household income has a positive relationship with violence. Moreover, according to their findings employed women are more likely to be a victim of spousal abuse, 
while, at the same time they found that women with personal income are less likely to experience abuse. They conclude that if working women can't retain control over their income may be the victim of IPV. Balci \& Ayranci(2005) and Y1lmaz(2017) found similar supporting evidence for the household bargaining theory in the case of Turkey. On the other hand, Kizilgol and Ipek(2018) found that the employment status of women and men has no significant effect on any type of abuse in Turkey. Erten and Keskin(2020) investigated the effect of women's employment on violence by exploiting the Syrian refugee inflow in Turkey as an exogenous labor market shock. According to their findings, refugee inflows simultaneously reduced women's employment opportunities and reduction in IPV against women which is supporting the male backlash theory.

\section{DATASETS, VARIABLES and METHODOLOGY}

\section{A. DATASETS}

This study mainly utilized the Turkish Statistical Institute's (TSI) "Domestic Violence Against Women in Turkey" survey which is conducted in 2014. In the sample design of this survey multistage stratified cluster sampling approach is used. The main purpose of this sampling design is to provide estimates of the main variables of the research on IPV against women such as age group, education level, and other socioeconomic status variables at a 95\% confidence interval for countrywide and the twelve regions and urban/rural strata. Following the Turkish Statistical Institute (TSI) sample selection approach, sampling frame, block selections, and block lists of selected samples are used as was provided by TSI.

Within the scope of the research, Turkey is divided into the country, urban/rural, 12 regions, and 5 regions which are counted up to 30 layers. Except for the Istanbul region, the distribution between urban and rural strata is at a rate of approximately $75 \%$ to $25 \%$ respectively. In Istanbul, however, about $5 \%$ of the households were selected from the rural regions. Settlements with a population of 10.000 and above constitute the urban strata, and those with a population less than 10.000 constitute the rural strata. 10.560 households were selected from urban strata and 4.512 households from rural strata.

TSI's study on Violence against Women in Turkey (2014) is the second most extensive research that has been conducted throughout the country to understand the size, nature, causes, consequences, and risk factors of domestic violence in Turkey. The scope of the survey is households that are included in all settlement territories of Turkey. The research was conducted with women aged between 15 and 59 in selected households. The sample of the research is cluster sampling. 330 of the clusters are urban and 188 of them are rural clusters. The sample of the study includes 7463 people.

Secondary data were used in this study. In the study, a micro data set of the Research on Domestic Violence Against Women in Turkey conducted by 
Hacettepe University Institute of Population Studies in 2014 was used. In order to use the data of the Research on Domestic Violence Against Women in Turkey in the article, official permission has been obtained from the Turkish Statistical Institute, which makes data sharing. In addition, a "Letter of Undertaking" has been given to the Turkish Statistical Institute for the use of microdata.

\section{B. SCALES and VARIABLES}

The dependent variable of the analysis is the state of exposure to violence which is measured by the following two questions:

Question 1) Has the woman been subjected to violence? (Yes or No).

Question 2) What kind of violence was the woman subjected to? (The woman was exposed to physical violence or, the woman was subjected to sexual violence or, the woman was exposed to both physical and sexual violence)

The dependent variable was created by combining these two questions as a variable with the four-potential reply. These are;

"Yes, she has been subjected to physical violence,

"Yes, she has been subjected to sexual violence,

"Yes, she has been subjected to both physical and sexual violence,

"No, she has not been subjected to any kind of violence".

To determine the independent variables authors benefited from a wide literature review and frequency distributions of those potential determinants of IPV are listed in Table 1. Independent variables are;residential statue (urban, rural), region (west, south, middle, north, east) age (15-25, 26-36, 37-47 and $48+$ ), native language (Turkish, Kurdish, Arabic, other), education (primary school, secondary school, high school, undergraduate, graduate), working (yes, no, no answer), Sectoral occupation (agriculture, industry, service, not working), sector (public, private, not working), employment status (unemployed, paid, business owner), health insurance (none, SGK, SSK, Emekli Sandığı, Bağ-Kur, Agricultural Insurance, Private Insurance, other), personal income status (no, yes), spouse education (primary school, secondary school, high school, undergraduate, graduate), spouse native language (Turkish, Kurdish, Arabic, other), spouse sectoral occupation (agriculture, industry, service, not working), spouse sector (public, private, unemployed), type of occupation ( not working, paid, business owner), spouse health insurance (none, SGK, SSK, Emekli Sandığı, Bağ-Kur, Agricultural Insurance, Private Insurance, other), has the spouse had a regular job in the past week (yes, no, doesn't know, did not answer), does he refuse you when you demand money (yes, no, she doesn't ask for it, did not answer), the spouse's seizure of income from the woman (yes, no, not suitable, no answer). 
Table 1: Frequency Distributions of Independent Variables

\begin{tabular}{|c|c|c|c|c|c|c|}
\hline \multirow{2}{*}{ Variable } & \multicolumn{4}{|c|}{ Victimization of Violence } & \multirow[t]{2}{*}{ Frequency $(\%)$} & \multirow[t]{2}{*}{$\mathbf{P}$} \\
\hline & $\mathbf{A}$ & B & $\mathbf{C}$ & D & & \\
\hline \multicolumn{7}{|c|}{ Residental Statue } \\
\hline Urban & $1081(66.8)$ & 90(70.9) & $411(67)$ & $3491(68.4)$ & $5073(68)$ & \multirow[t]{2}{*}{0.541} \\
\hline Rural & $537(33.2)$ & $37(29.1)$ & 202(33) & $1613(31.6)$ & $2389(32)$ & \\
\hline \multicolumn{7}{|c|}{ Region (Reference Category: East) } \\
\hline West & $489(30.2)$ & $38(29.9)$ & $202(33)$ & $1624(31.8)$ & $2353(31.5)$ & 0.531 \\
\hline South & $145(9)$ & $9(7.1)$ & $53(8.6)$ & $397(7.8)$ & $604(8.1)$ & 0.432 \\
\hline Mid. & $449(27.8)$ & $23(18.1)$ & $139(22.7)$ & $970(19)$ & $1581(21.2)$ & $0.000 *$ \\
\hline North & $175(10.8)$ & $15(11.8)$ & $68(11.1)$ & $787(15.4)$ & $1045(14)$ & $0.000 *$ \\
\hline East & $360(22.2)$ & $42(33.1)$ & $151(24.6)$ & $1326(26)$ & $1879(25.2)$ & $0.004 *$ \\
\hline \multicolumn{7}{|c|}{ Age (Reference Category: 15-25) } \\
\hline $15-25$ & $143(8.8)$ & $18(14.2)$ & $39(6.4)$ & $1345(26.4)$ & $1545(20.7)$ & $0.000 *$ \\
\hline $26-36$ & $532(32.9)$ & $46(36.2)$ & $212(34.6)$ & $1613(31.6)$ & $2403(32.2)$ & 0.294 \\
\hline $37-47$ & $500(30.9)$ & $32(25.2)$ & $187(30.5)$ & $1189(23.3)$ & $1908(25.6)$ & $0.000 *$ \\
\hline $48+$ & $443(27.4)$ & $31(24.4)$ & $175(28.5)$ & $957(18.8)$ & $1606(21.5)$ & $0.000 *$ \\
\hline \multicolumn{7}{|c|}{ Education (Reference Category: Primary School) } \\
\hline Primary & $861(53.2)$ & $61(48)$ & $335(54.6)$ & $2044(40)$ & $3301(44.2)$ & $0.000 *$ \\
\hline Secondary & $201(12.4)$ & & $67(10.9)$ & $568(11.1)$ & $855(1$ & 0.292 \\
\hline High school & $196(12.1)$ & $19(15)$ & $68(11.1)$ & $1173(23)$ & $1456(19.5)$ & $0.000 *$ \\
\hline Undergraduate & $91(5.6)$ & $6(4.7)$ & $26(4.2)$ & $710(13.9)$ & $833(11.2)$ & $0.000 *$ \\
\hline Graduate & $6(0.4)$ & $2(1.6)$ & $1(0.2)$ & $43(0.8)$ & $52(0.7)$ & 0.046 \\
\hline No answer & $263(16.3)$ & $20(15.7)$ & $116(18.9)$ & $566(11.1)$ & $965(12.9)$ & $0.000 *$ \\
\hline \multicolumn{7}{|c|}{ Have you worked in any kind of job in the past week. whether paid or not? } \\
\hline Yes & $342(21.1)$ & $25(19.7)$ & $154(25.1)$ & $1019(20)$ & $1540(20.6)$ & \multirow[t]{2}{*}{0.102} \\
\hline No & $1276(78.9)$ & $102(80.3)$ & $459(74.9)$ & $4082(80)$ & 5919(79.4) & \\
\hline \multicolumn{7}{|c|}{ Do you have a regular job? (Reference Category: No) } \\
\hline Yes & $23(1.4)$ & $2(1.6)$ & $17(2.8)$ & $115(2.3)$ & $157(2.1)$ & 0.126 \\
\hline No & $1114(68.9)$ & $85(66.9)$ & $388(63.3)$ & $3623(71)$ & $5210(69.8)$ & $0.001 *$ \\
\hline No Answer & $481(29.7)$ & $40(31.5)$ & 208(33.9) & $1366(26.8)$ & $2095(28.1)$ & $0.001 *$ \\
\hline \multicolumn{7}{|c|}{ Do you have any earnings or income of your own? } \\
\hline Yes & $394(24.4)$ & $28(22)$ & $161(26.3)$ & $1184(23.2)$ & $1767(23.7)$ & \multirow[t]{2}{*}{0.319} \\
\hline No & $1224(75.6)$ & 99(78) & $452(73.7)$ & $3920(76.8)$ & $5695(76.3)$ & \\
\hline \multicolumn{7}{|c|}{$\begin{array}{l}\text { In a case of emergency can you find money that is enough for } 1 \text { month to feed your } \\
\text { household? }\end{array}$} \\
\hline Yes & $629(38.9)$ & $43(33.9)$ & $193(31.5)$ & $2396(46.9)$ & $3261(43.7)$ & \multirow[t]{2}{*}{$0.000 *$} \\
\hline No & $989(61.1)$ & $84(66.1)$ & $420(68.5)$ & $2708(53.1)$ & $4201(56.3)$ & \\
\hline \multicolumn{7}{|c|}{ Has your spouse worked in any type of job in the past week? (Reference Category: Yes) } \\
\hline Yes & $1181(73)$ & $97(76.4)$ & $429(70)$ & $3333(65.3)$ & $5040(67.5)$ & $0.000 *$ \\
\hline No & $432(26.7)$ & $29(22.8)$ & $180(29.4)$ & $1083(21.2)$ & $1724(23.1)$ & $0.000^{*}$ \\
\hline Doesn't Know & $5(0.3)$ & $1(0.8)$ & $4(0.7)$ & $688(13.5)$ & $698(9.4)$ & $0.000 *$ \\
\hline \multicolumn{7}{|c|}{ Industry that your spouse work? (Reference Category: Not Working) } \\
\hline Public & $187(11.6)$ & $11(8.7)$ & $51(8.3)$ & $623(12.2)$ & $872(11.7)$ & 0.027 \\
\hline Private & $1115(68.9)$ & $91(71.7)$ & $417(68)$ & $2961(58)$ & $4584(61.4)$ & $0.000 *$ \\
\hline Not Working & $316(19.5)$ & $25(19.7)$ & $145(23.7)$ & $1520(29.4)$ & $2006(26.9)$ & $0.000 *$ \\
\hline
\end{tabular}


Tablo 1'in devamı...

\begin{tabular}{|c|c|c|c|c|c|c|}
\hline \multirow{2}{*}{ Variable } & \multicolumn{4}{|c|}{ Victimization of Violence } & \multirow{2}{*}{$\begin{array}{l}\text { Frequency } \\
(\%)\end{array}$} & \multirow[t]{2}{*}{$\mathbf{P}$} \\
\hline & $\mathbf{A}$ & B & $\mathrm{C}$ & D & & \\
\hline \multicolumn{7}{|c|}{ Is your spouse attached to any social security institution? (Reference Category: BAG-KUR) } \\
\hline SGK & $65(4)$ & $4(3.1)$ & $31(5.1)$ & $219(4.3)$ & $319(4.3)$ & 0.665 \\
\hline SSK & $619(38.3)$ & $47(37)$ & $222(36.2)$ & $1762(34.5)$ & $2650(35.5)$ & 0.051 \\
\hline Emekli Sandığ1 & $102(6.3)$ & $4(3.1)$ & $23(3.8)$ & $402(7.9)$ & $531(7.1)$ & $0.000 *$ \\
\hline BAĞ-KUR & $180(11.1)$ & $20(15.7)$ & $65(10.6)$ & $430(8.4)$ & $695(9.3)$ & $0.000 *$ \\
\hline Other & $25(1.5)$ & $1(0.8)$ & $14(2.3)$ & $74(1.4)$ & $114(1.5)$ & 0.391 \\
\hline None & $624(38.6)$ & $50(39.4)$ & $255(41.6)$ & $2204(43.2)$ & $3133(42)$ & 0.011 \\
\hline \multicolumn{7}{|c|}{ Does your spouse allow you to work in a job? (Reference Category: No) } \\
\hline Yes & $485(30)$ & $41(32.3)$ & $249(40.6)$ & $696(13.6)$ & $1471(19.7)$ & $0.000 *$ \\
\hline No & $1009(62.4)$ & $74(58.3)$ & $313(51.1)$ & $3390(66.4)$ & $4786(64.1)$ & $0.000 *$ \\
\hline No answer & $124(7.7)$ & $12(9.4)$ & $51(8.3)$ & $1018(19.9)$ & $1205(16.1)$ & $0.000 *$ \\
\hline \multicolumn{7}{|c|}{ Has your spouse refused to give you money for household needs? (Reference Category: No) } \\
\hline Yes & $214(13.2)$ & $17(13.4)$ & $224(36.5)$ & $112(2.2)$ & $567(7.6)$ & $0.000 *$ \\
\hline No & 1382(85.4) & $109(85.8)$ & $382(62.3)$ & 4048(79.3) & $5921(79.3)$ & $0.000 *$ \\
\hline No answer & $22(1.4)$ & $1(0.8)$ & $7(1.1)$ & $944(18.5)$ & $974(13.1)$ & $0.000 *$ \\
\hline \multicolumn{7}{|c|}{$\begin{array}{l}\text { Did your spouse take away your income even though you did not want it? (Reference } \\
\text { Category: No) }\end{array}$} \\
\hline Yes & $106(6.6)$ & $8(6.3)$ & $149(24.3)$ & $48(0.9)$ & $311(4.2)$ & $0.000^{*}$ \\
\hline No & $1343(83)$ & $102(80.3)$ & $396(64.6)$ & $3867(75.8)$ & $5708(76.5)$ & $0.000 *$ \\
\hline No answer & $169(10.4)$ & $17(13.4)$ & $68(11.1)$ & $1189(23.3)$ & $1143(19.3)$ & $0.000 *$ \\
\hline : subjected to & iniol & B: subj & - & olence. C & & physica \\
\hline
\end{tabular}

According to Table 1, 68\% of the individuals in the study reside in the city. It is seen that the individuals participating in the study mostly live in western regions (32\%). The highest participation is in the 26-36 age group. While $44 \%$ of individuals are primary school graduates, $11 \%$ are university graduates. The rate of women who stated that they do not have a regular job is $70 \%$. $23 \%$ of the women included in the study have their own income or earnings. $23 \%$ of the women stated that their spouses have not worked in any job in the last week.

\section{MULTINOMIAL PROBIT MODEL}

Multinomial probit model is expressed as a random utility function model that includes error terms with zero mean, arbitrary variance-covariable matrix, and co-multivariate normal distribution in this case, the variances of the error terms in the multinomial probit model may be different and related (Daganzo, 1979: 17). Moreover, the multinomial probit model is closely associated with a multiperiod probit model in which a binary choice decision is seen over multiple periods with correlated errors (McCulloch and Rossi, 1994: 207-208). Although the multi-state probit model is among the interesting models among the preference behavior models, thanks to the fact that it gives flexibility to the conditional covariable property among the hidden benefits of alternatives, 
it is not widely used in the literature because of the problem of calculation difficulty of the highest likelihood estimator in practice. However, the fact that the multistate probit model attenuates the assumption of the independence of unrelated alternatives is accepted as an advantage over the multistate logit model as a rule (Geweke, Keane and Runkle,1994).

One way to relax the independence assumption in the multinomial logit model is to use the multinomial probit model. The structural equations of the multinomial probit model are as follows:

$$
U_{i j}=x_{i j}^{\prime}+\varepsilon_{i j}, j=1, \ldots, J,\left[\varepsilon_{i 1}, \varepsilon_{i 2}, \ldots, \varepsilon_{i j}\right] \sim N[0, \Sigma] .
$$

The log-likelihood term corresponding to the option q:

$$
\operatorname{Prob}\left[o p t_{i q}\right]=\operatorname{Prob}\left[U_{i q}>U_{i j}, j=1, \ldots, J, j \neq q\right] .
$$

The probability of this happening for the other $\mathrm{J}-1$ option is:

$$
\begin{aligned}
& \operatorname{Prob}\left[o p t_{i q}\right]=\operatorname{Prob}\left[\varepsilon_{i 1}-\varepsilon_{i q}<\left(x_{i q}-x_{i 1}\right)^{\prime} \beta, \ldots, \varepsilon_{i j}-\varepsilon_{i q}<\right. \\
& \left.\left(x_{i q}-x_{i 1}\right)^{\prime} \beta\right] .
\end{aligned}
$$

It is the cumulative probability of the normal distribution with $\mathrm{J}-1$ variables. The multinomial probit model allows for an unbounded $\mathrm{J}-1 \times \mathrm{J}-1$ correlation structure and J-2 independent standard deviation values (Greene, 2012, pp. 770-771).

The reason why the multinomial probit model is preferred to the multinomial logit model is independence assumption of irrelevant alternatives(IIA). If this assumption is violated, the estimated coefficients are biased and inconsistent. In this study, we implement the multinomial probit (MNP) model to analyze the determinants of employment and financial empowerment of women on domestic violence which empower for the error correlations along with the predicted coefficients. Alvarez and Nagler (1998) stated that the multinomial probit model gives more accurate predictions than the logit model, which does not require the IIA assumption.

To evaluate the relative impact of the different violence factors and to make binary comparisons between different types of violence, the marginal effects of individual variables on the probability of exposure to each type of violence were estimated.

\section{FINDINGS}

Multinomial probit regression model was used to determine the factors affecting violence against women over 15 years of age in the study. The estimation results of the multinomial probit regression model are given in Table 2. 
Default group in the predicted multinomial probit model is the case of "not being subjected to both physical and sexual violence" where the dependent variable takes the value 4 . The coefficient interpretation cannot be made from the estimated model, only the signs of the variables can be determined through this model.

Table 2: Model Estimation Results

\begin{tabular}{|c|c|c|c|c|c|c|c|}
\hline & \multicolumn{2}{|l|}{$\mathbf{A}$} & \multicolumn{2}{|l|}{$\mathbf{B}$} & \multicolumn{2}{|l|}{$\mathbf{C}$} & \multirow[t]{2}{*}{ VIF } \\
\hline & $\beta$ & S.E. & $\beta$ & S.E. & $\beta$ & S.E. & \\
\hline \multicolumn{8}{|c|}{ Residental Statue (Reference Category: Rural) } \\
\hline Urban & -0.068 & 0.058 & 0.103 & 116 & -0.087 & 076 & 1.24 \\
\hline \multicolumn{8}{|c|}{ Region (Reference Category: East) } \\
\hline West & 0.044 & 0.074 & 20 & 137 & 0.141 & 096 & 1.59 \\
\hline & & & & 201 & 0.138 & 132 & 190 \\
\hline & & & & 149 & $0.218^{* *}$ & 102 & 1.64 \\
\hline & & 0.090 & & 0.174 & -0.190 & .120 & 1.52 \\
\hline \multicolumn{8}{|c|}{ rence Category: 15-25 Years) } \\
\hline & $0.301 * * *$ & 0.088 & & 164 & $2 * * *$ & 127 & 2.52 \\
\hline & & & & 77 & $1 * * *$ & 33 & $\cdots$ \\
\hline & 0.70 & 0.099 & & 37 & $1 * * *$ & & 2. \\
\hline \multicolumn{8}{|c|}{ Education (Reference Category: Primary School) } \\
\hline & & 0.084 & & & 0.003 & 113 & 1.25 \\
\hline & & & & & $49 * * *$ & 99 & 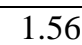 \\
\hline & & & & & $8^{* * * *}$ & & 1.5 \\
\hline & & & & & -0.994 & 32 & 1.0 \\
\hline No Ar & $154 * *$ & 0.076 & 0.080 & 0.147 & $0.249 * * *$ & 0.095 & 1.2 \\
\hline \multicolumn{8}{|c|}{$\begin{array}{l}\text { Have you worked in any kind of job in the past week. whether paid or not? } \\
\text { (Reference Category:No) }\end{array}$} \\
\hline & -0.063 & 0.092 & 0.032 & 0.161 & & 0.133 & 2. \\
\hline \multicolumn{8}{|c|}{ r job? (Reference } \\
\hline Yes & $-0.340 *$ & 0.191 & & 0.375 & 0.223 & 0.222 & 1.09 \\
\hline No Answer & 0.001 & 0.089 & 0.252 & 0.157 & 0.045 & 0.123 & 2.8. \\
\hline \multicolumn{8}{|c|}{ Do you have any earnings or income of your own? (Referen } \\
\hline & $168 * *$ & 0.076 & 026 & 0.149 & 0.032 & 0.099 & 1.8 \\
\hline \multicolumn{8}{|c|}{$\begin{array}{l}\text { In a case of emergency. can you find money that is enough for } 1 \text { month to feed your } \\
\text { household? (Reference Category: No) }\end{array}$} \\
\hline Yes & $-0.120 * *$ & 0.054 & $-0.259 * *$ & 0.109 & $-0.282 * * *$ & 0.073 & 1.2. \\
\hline \multicolumn{8}{|c|}{ Does the spouse have a regular job? (Reference Category: Yes) } \\
\hline & & & & & & 32 & 3. \\
\hline & $-1.295 * * *$ & 0.302 & -0.756 & 0.616 & $-1.063 * * *$ & 0.410 & 4. \\
\hline \multicolumn{8}{|c|}{ ategory: Not $\mathrm{V}$} \\
\hline & & 0.1 & & 0.315 & 0.054 & 0.202 & 4. \\
\hline Private & $0.308^{* * * *}$ & 0.11 & $.075^{* *}$ & 0.247 & 0.012 & 153 & 6.1 \\
\hline
\end{tabular}


Tablo 2'nin devamı...

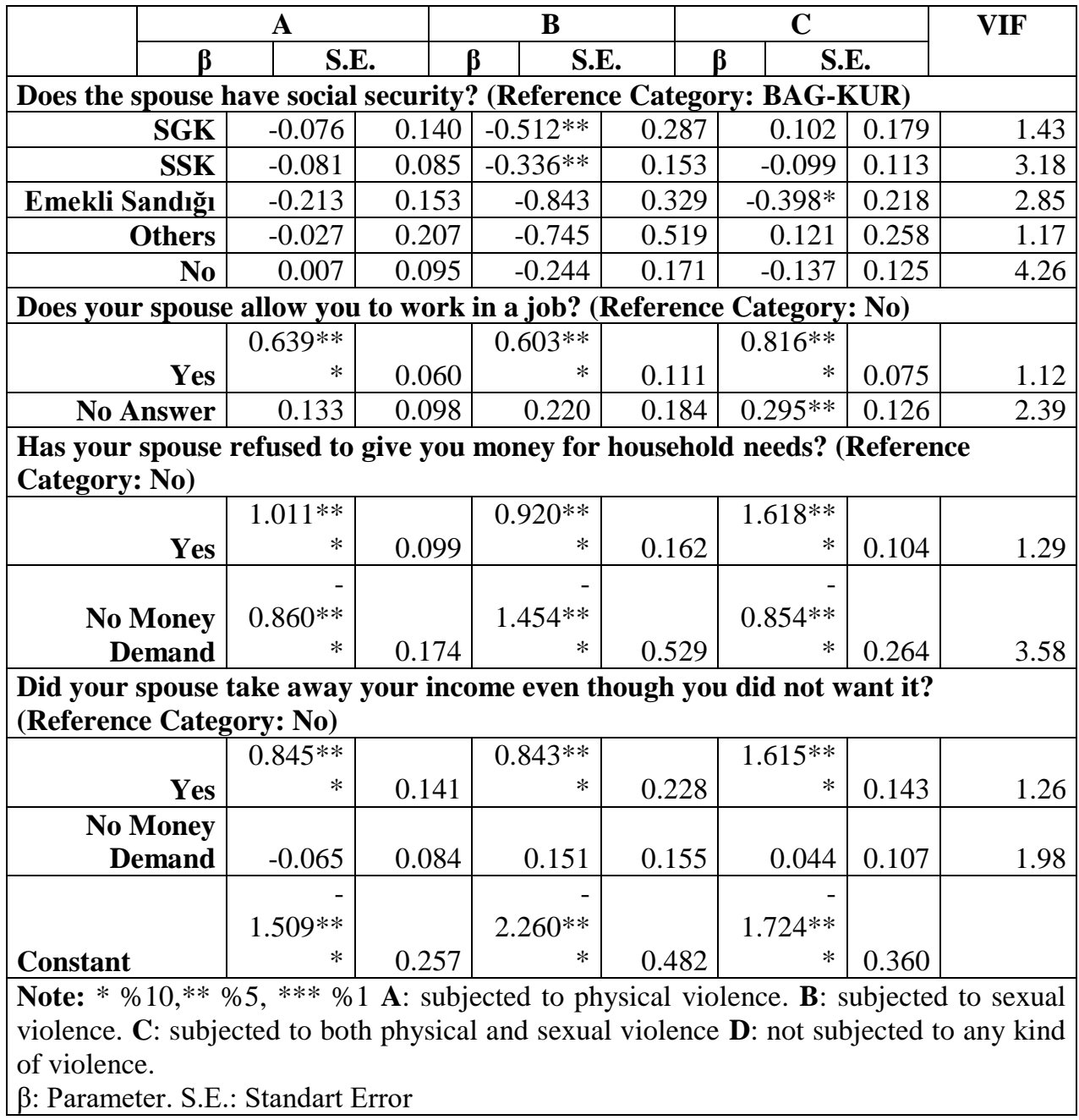

It is found that the odds of physical violence against women has been in the same direction with the following conditions; region, age, some categories of education, having a personal income, spouse working status, spouse sector, refusal of spouse in the case of women's desire to work, spouse doesn't give money to the woman, spouse seizures of women's income.

On the other hand, the following conditions are found to be at the opposite direction with the odds of IPV against women; living in the northern regions, high school or higher level of education, having a job, women's ability to find enough money to meet their needs in a case of emergency, some of the categories of refusal of the spouse to give money to the woman. 
Moreover, sexual violence against women has been positively correlated with spouse permission to women's work desire, the spouse's refusal to money demand of the woman, and seizure of women's money by the spouse. Oppositely, being a university graduate, the woman's ability to find enough money to meet her needs in a case of emergency, and spouse's possession of health insurance is found to be negatively related to odds of sexual violence.

Table 3 shows the marginal effects estimations of the model. According to the estimations expressed in Table 3, it has been found that the place of residence has a significant effect on the violence. According to findings, individuals living in the southern region were more likely to be exposed to physical violence by $3.8 \%$ than those living in the eastern region, while people living in the middle regions more likely to be exposed to physical violence by $9 \%$, than those living in the eastern region. However, women living in the northern regions are found to be less likely to be victimized with IPV compared to women living in the eastern region by $3.6 \%$.

Table 3: Marginal Effects

\begin{tabular}{|c|c|c|c|c|c|c|c|c|}
\hline & \multicolumn{2}{|l|}{$\mathbf{A}$} & \multicolumn{2}{|l|}{ B } & \multicolumn{2}{|l|}{$\mathbf{C}$} & \multicolumn{2}{|l|}{$\mathbf{D}$} \\
\hline & $\mathrm{dy} / \mathrm{dx}$ & S.E. & dy/dx & S.E. & $\mathrm{dy} / \mathrm{dx}$ & S.E. & $\mathrm{dy} / \mathrm{dx}$ & S.E. \\
\hline \multicolumn{9}{|c|}{ Residental Statue (Reference Category: Rural) } \\
\hline Urban & -0.013 & 0.011 & 0.004 & 0.003 & -0.006 & 0.006 & 0.015 & 0.013 \\
\hline \multicolumn{9}{|c|}{ Region (Reference Category: East) } \\
\hline West & 0.007 & 0.014 & $-0.007 *$ & 0.003 & 0.012 & 0.008 & -0.012 & 0.016 \\
\hline South & $0.038^{*}$ & 0.021 & $-0.007 *$ & 0.004 & 0.008 & 0.012 & $-0.039 *$ & 0.023 \\
\hline Mid. & $0.089 *$ & 0.017 & $-0.008^{*}$ & 0.003 & 0.008 & 0.009 & $-0.090 *$ & 0.018 \\
\hline North & $-0.036^{*}$ & 0.016 & -0.007 & 0.004 & -0.010 & 0.009 & $0.052 *$ & 0.018 \\
\hline \multicolumn{9}{|c|}{ Age (Reference Category: 15-25 Years) } \\
\hline 26-36 & $0.053 *$ & 0.018 & -0.001 & 0.005 & $0.024 *$ & 0.012 & $-0.076^{*}$ & 0.020 \\
\hline $37-47$ & $0.080^{*}$ & 0.020 & -0.002 & 0.005 & $0.026 *$ & 0.013 & $-0.104 *$ & 0.022 \\
\hline 48 and over & $0.084 *$ & 0.022 & 0.001 & 0.005 & $0.036^{*}$ & 0.014 & $-0.121 *$ & 0.024 \\
\hline \multicolumn{9}{|c|}{ Education (Reference Category: Primary School) } \\
\hline Middle School & 0.022 & 0.017 & 0.007 & 0.006 & -0.003 & 0.009 & -0.026 & 0.019 \\
\hline High School & $-0.056^{*}$ & 0.013 & 0.001 & 0.004 & $-0.020 *$ & 0.007 & $0.075^{*}$ & 0.016 \\
\hline Undergraduate & $-0.093 *$ & 0.015 & -0.005 & 0.005 & $-0.034 *$ & 0.008 & $0.132 *$ & 0.017 \\
\hline Graduate & $-0.108 *$ & 0.038 & 0.038 & 0.037 & $-0.043 *$ & 0.015 & $0.113 *$ & 0.053 \\
\hline No Answer & 0.025 & 0.015 & 0.000 & 0.004 & $0.019 *$ & 0.009 & $-0.044 *$ & 0.018 \\
\hline \multicolumn{9}{|c|}{$\begin{array}{l}\text { Have you worked in any kind of job in the past week. whether paid or not? (Reference } \\
\text { Category:No) }\end{array}$} \\
\hline Yes & -0.007 & \begin{tabular}{l|l|}
0.018 \\
\end{tabular} & 0.002 & 0.005 & $-0.021 * *$ & 0.011 & 0.026 & 0.020 \\
\hline \multicolumn{9}{|c|}{ Do you have a regular job? (Reference Category: No) } \\
\hline Yes & $-0.066^{*}$ & 0.028 & 0.002 & 0.012 & 0.031 & 0.025 & 0.034 & 0.038 \\
\hline No answer & -0.003 & 0.017 & 0.008 & 0.005 & 0.003 & 0.010 & -0.008 & 0.020 \\
\hline \multicolumn{9}{|c|}{ Do you have any earnings or income of your own? (Reference Category: No) } \\
\hline Yes & $0.034^{*}$ & 0.015 & -0.001 & 0.004 & -0.001 & 0.008 & $-0.032 *$ & 0.017 \\
\hline
\end{tabular}


Tablo 3'ün devamı...

\begin{tabular}{|c|c|c|c|c|c|c|c|c|}
\hline & \multicolumn{2}{|c|}{$\mathbf{A}$} & \multicolumn{2}{|l|}{ B } & \multicolumn{2}{|l|}{$\mathbf{C}$} & \multicolumn{2}{|l|}{ D } \\
\hline & $\mathrm{dy} / \mathrm{dx}$ & S.E. & $\mathrm{dy} / \mathrm{dx}$ & S.E. & $\mathrm{dy} / \mathrm{dx}$ & S.E. & $\mathrm{dy} / \mathrm{dx}$ & S.E. \\
\hline \multicolumn{9}{|c|}{$\begin{array}{l}\text { In a case of emergency. can you find money that is enough for } 1 \text { month to feed your } \\
\text { household? (Reference Category: No) }\end{array}$} \\
\hline Yes & -0.016 & 0.010 & $-0.006^{*}$ & 0.003 & $0.020 * * *$ & 0.006 & $0.041 *$ & 0.012 \\
\hline \multicolumn{9}{|c|}{ Does the spouse have a regular job? (Reference Category: Yes) } \\
\hline No & $0.050 *$ & 0.020 & -0.005 & 0.005 & 0.009 & 0.011 & $-0.054 *$ & 0.023 \\
\hline Doesn't know & $-0.164 *$ & 0.023 & -0.008 & 0.010 & $-0.043 *$ & 0.013 & $0.216^{*}$ & 0.028 \\
\hline \multicolumn{9}{|c|}{ Industry that your spouse work? (Reference Category: Not Working) } \\
\hline Public & $0.070 *$ & 0.033 & -0.002 & 0.008 & -0.004 & 0.016 & $-0.064 *$ & 0.036 \\
\hline Private & $0.061 *$ & 0.021 & -0.005 & 0.008 & -0.006 & 0.012 & $-0.051 *$ & 0.025 \\
\hline \multicolumn{9}{|c|}{ Does the spouse have social security? (Reference Category: BAG-KUR) } \\
\hline SGK & -0.015 & 0.026 & $-0.010 * *$ & 0.004 & 0.012 & 0.017 & 0.012 & 0.030 \\
\hline SSK & -0.011 & 0.016 & $-0.008^{*}$ & 0.004 & -0.005 & 0.009 & 0.025 & 0.019 \\
\hline Emekli Sandığı & -0.029 & 0.027 & $-0.013 *$ & 0.003 & $-0.023 *$ & 0.012 & $0.065^{*}$ & 0.030 \\
\hline Others & -0.005 & 0.039 & $-0.012 *$ & 0.004 & 0.013 & 0.024 & 0.004 & 0.045 \\
\hline None & 0.006 & 0.018 & -0.007 & 0.005 & -0.011 & 0.010 & 0.011 & 0.021 \\
\hline \multicolumn{9}{|c|}{ Does your spouse allow you to work in a job? (Reference Category: No) } \\
\hline Yes & $0.109^{*}$ & 0.013 & $0.011 * *$ & 0.004 & $0.063 *$ & 0.009 & $-0.183^{*}$ & 0.015 \\
\hline No answer & 0.018 & 0.020 & 0.005 & 0.006 & $0.023 *$ & 0.012 & $-0.046^{*}$ & 0.023 \\
\hline \multicolumn{9}{|c|}{$\begin{array}{l}\text { Has your spouse refused to give you money for household needs? (Reference Category: } \\
\text { No) }\end{array}$} \\
\hline Yes & $0.146^{*}$ & 0.023 & $0.012^{*}$ & 0.007 & $0.189 *$ & 0.021 & $-0.347 *$ & 0.027 \\
\hline $\begin{array}{r}\text { No Money } \\
\text { Demand }\end{array}$ & $-0.122 *$ & 0.021 & $-0.018 *$ & 0.004 & $-0.039 *$ & 0.012 & $0.178^{*}$ & 0.024 \\
\hline \multicolumn{9}{|c|}{$\begin{array}{l}\text { Did your spouse take away your income even though you did not want it? (Reference } \\
\text { Category: No) }\end{array}$} \\
\hline Yes & $0.100^{*}$ & 0.030 & 0.011 & 0.010 & $0.212 *$ & 0.029 & $-0.323^{*}$ & 0.039 \\
\hline $\begin{array}{r}\text { No Money } \\
\text { Demand }\end{array}$ & -0.015 & 0.015 & 0.005 & 0.005 & 0.005 & 0.009 & 0.005 & 0.018 \\
\hline te: $*$ indicate & . & sigi & $\mathbf{A}:$ & te & pinysic & 016 & $\mathrm{~s}$ & d to \\
\hline
\end{tabular}

It has been seen that the educational status of women is also an important factor in their exposure to IPV. Accordingly, compared to primary school graduates, high school graduates by $5.6 \%$, university graduates by $9.3 \%$, and postgraduates were found to be less likely to be exposed to physical violence by $\% 10.76$. Similarly, a reduction in the risk of both physical and sexual violence has been observed regarding the educational status.

Besides education age is an important factor in violence against women, since according to estimation findings older women are more likely to experience physical violence than younger women. According to findings, women aged between $26-36$ is 5.3\% more likely, women aged between $37-47$ $8 \%$ more likely, and women older than 47 are $8.4 \%$ more likely to experience 
physical violence than women aged between 15-25. In the case of the risk of both sexual and physical violence, similar results have been found.

Women who were working in the past week, whether paid or not, are $2.1 \%$ less likely to be subjected to both physical and sexual violence than those who do not work. Also, it was found that women who have a regular job are $6.6 \%$ less likely to be exposed to physical violence than those who do not. Women who stated that they could find enough money to meet their one-month needs in a case of emergency were found to be $2 \%$ less likely to be subjected to both physical and sexual violence compared to those who could not.

On the other hand, women who have an income are $3.4 \%$ more likely to experience physical violence than those who do not. Moreover, women whose husbands do not work in a regular job were found to be $5 \%$ more likely to experience physical violence and $5.4 \%$ less likely do not to experience both physical and sexual violence compared to those who work. Nonetheless, women who are allowed to work by their spouses are $10.9 \%$ more likely to be exposed to physical violence, $1.1 \%$ more likely to be subjected to sexual violence, and $6.3 \%$ more likely to be subjected to both physical and sexual violence.

It was observed that women who are not given money by their spouse to meet the needs of the house are $14.6 \%$ more likely to be subjected to physical violence and $18.9 \%$ more likely to be subjected to both physical and sexual violence than the others. Women who do not ask for money from their spouses for the needs of the house are $12.2 \%$ less likely to be subjected to physical violence, and $0.39 \%$ less likely to be subjected to both physical and sexual violence than women who ask but can't receive money. Besides, women whose income was taken away were $10 \%$ more likely to be subjected to physical violence and $21.2 \%$ more likely to be subjected to both physical and sexual violence compared to those who were not.

\section{CONCLUSION AND DISCUSSION}

This paper presents information about physical and sexual violence from a population-based survey among women in Turkey. The relationship between socioeconomic factors and domestic violence is investigated through Multinomial Probit Model. Our Multinomial Probit Model estimation findings show mixed results regarding the IPV.

Looking at the working condition of women in the last week, the condition of having a regular job and having fund enough for four weeks to meet the needs of the household we see that working and having emergency fund reduced some types of IPV. Therefore, it might be instrumental to improve labor market conditions for women and providing positive discrimination in the job market to reduce the likelihood of IPV among Turkish women. 
On the other hand, looking to the positive signed variables that having any type of personal income and spouse with a regular job implies a rising risk of IPV per the male backlash theory. When male patriarchy is no longer fully secure in modern times, masculinist restoration is used to ensure its reproduction, which is defined as higher levels of coercion together with the deployment of more varied ideological apparatuses (Kandiyoti, 2016). The masculinist restoration can explain the underlying mechanism of the Male Backlash theory.

This result, besides the economic factors, may highlight the effect of sociocultural factors that trigger the culture of IPV. The patriarchal social and cultural framework in Turkey that gives rise to male control over women and condones violence against women should be controlled by diminishing the levels of childhood exposures to violence; revising discriminatory family law; advancing women's economic and legal rights; and stopping gender inequality in access to formal wage employment and education (WHO, 2013).

As it is seen from the estimation findings as economic violence increases against women odds of physical and sexual violence increases significantly. Women who refused by their spouse in the case of money demand for household needs are significantly more likely to experience both physical and sexual violence. Moreover, women whose income is taken away are more likely to experience physical and sexual violence. Therefore, apart from the sociocultural factors, poverty in families may be an important source of IPV in Turkey. Since relatively high unemployment rates and lack of regular income conditions may be the sources of conflict in families. Considering the limited source of income in families that suffer from unemployment problems, conflict among couples regarding the distribution of income among alternative types of expenditures may be a source of IPV.

Age is a significantly important factor too, in the case of IPV. According to estimation results, in comparison with the women aged between 26 and 36 , elder women more likely to be victimized by their spouses. This may be interpreted as the effect of patriarchal cultural norms and customs which are more widely prevalent and acknowledged among older generations than the younger. The importance of education comes into play here, since not only men even women are seen to accepted male dominance. To change this situation, a consciousness of women's rights must be spread in society.

We can see the importance of education in the statistical findings of our model too. According to findings as women's educational status rises the likelihood of violence decreases significantly. Therefore, while education is the most important source to enrich human capital, it seems that it may help to eliminate violence against females and guaranteeing basic human rights. 
Finally, the model estimation results should be considered with precaution. Since the definition of violence may vary from culture to culture, region to region. Especially in developing countries like Turkey, domestic violence may not yet be considered as a major problem, in spite of its rising prevalence and severe outcomes. Since, domestic violence may be seen as a private matter and a potentially justifiable reaction to the misbehavior of the women (Alhabib, Nur and Jones, 2010).

Moreover, due to data limitations psychological or emotional violence against women could not be investigated. While employment may reduce the likelihood of physical violence, levels of emotional violence may increase as women get financially independent and more educated. Since physical violence against an intimate partner is mostly prohibited and punished vigorously in the western world, physical violence has been transforming into psychological or emotional violence gradually. Therefore, this is another limitation of our work and it can be a potential future research topic for interested scholars.

Therefore, actual occurrences of domestic violence and its effect may be higher than the survey and model estimation results imply, since women may not answer survey questions appropriately. This eventuality reflects itself mostly in the sexual violence estimation results which are found to be less significantly meaningful or not meaningful, in some cases, in proportion to physical violence. Since women do not generally know the meaning of sexual violence or may not know the difference between a healthy sexual life and sexual violence by the spouse.

\section{REFERENCES}

Aizer, A. (2010). The gender wage gap and domestic violence. American Economic Review, 100(4), 1847-59.

Alan, H., Yilmaz, S. D., Filiz, E., \& Arioz, A. (2016). Domestic violence awareness and prevention among married women in Central Anatolia. Journal of Family Violence, 31(6), 711-719.

Alhabib, S., Nur, U., \& Jones, R. (2010). Domestic violence against women: Systematic review of prevalence studies. Journal of Family Violence, 25(4), 369-382.

Alvarez, R. M., \& Nagler, J. (1998). When politics and models collide: Estimating models of multiparty elections. American Journal of Political Science, 55-96.

Anderberg, D., Rainer, H., Wadsworth, J., \& Wilson, T. (2016). Unemployment and domestic violence: Theory and evidence. The Economic Journal, 126(597), 1947-1979. 
Balci, Y. G., \& Ayranci, U. (2005). Physical violence against women: Evaluation of women assaulted by spouses. Journal of Clinical Forensic Medicine, 12(5), 258-263.

Bamiwuye, S. O., \& Odimegwu, C. (2014). Spousal violence in sub-Saharan Africa: does household poverty-wealth matter?. Reproductive Health, 11(1), 1-10.

Bhattacharya, S., \& Bhattacharya, S. (2014). Battered and shattered: will they get justice? A study of domestic violence against women in India based on National Family Health Survey, 2005. The Journal of Adult Protection.

Bowlus, A. J., and Seitz, S. (2006). Domestic violence, employment, and divorce. International Economic Review, 47(4), 1113-1149.

Brown, L., Thurman, T., Bloem, J., \& Kendall, C. (2006). Sexual violence in Lesotho. Studies in Family Planning, 34(4)

Brownridge, D. A., \& Halli, S. S. (2002). Double jeopardy?: Violence against immigrant women in Canada. Violence and Victims, 17(4), 455-471. https://doi.org/10.1891/vivi.17.4.455.33680

Burazeri, G., Roshi, E., Jewkes, R., Jordan, S., Bjegovic, V., \& Laaser, U. (2005). Factors associated with spousal physical violence in Albania: cross sectional study. Bmj, 331(7510), 197-201.

Castro, R., Peek-Asa, C., \& Ruiz, A. (2003). Violence against women in Mexico: a study of abuse before and during pregnancy. American Journal of Public Health, 93(7), 1110-1116.

Chin, Y. M. (2012). Male backlash, bargaining, or exposure reduction?: women's working status and physical spousal violence in India. Journal of Population Economics, 25(1), 175-200.

Chin, Y. M., Song, J. J., \& Stamey, J. D. (2017). A Bayesian approach to misclassified binary response: female employment and intimate partner violence in urban India. Applied Economics Letters, 24(20), 1439-1442.

Daganzo, C. F. (1979). The statistical interpretation of predictions with disaggregate demand models. Transportation Science, 13(1), 1-12.

Dikmen, H. A., \& Munevver, G. I. (2020). The relationship between domestic violence and the attitudes of women towards honor, gender roles, and wife-beating in Turkey. Archives of Psychiatric Nursing, 34(5), 421426. 
Dugan, L., Nagin, D. S., \& Rosenfeld, R. (2003). Exposure reduction or retaliation? The effects of domestic violence resources on intimatepartner homicide. Law \& Society Review, 37(1), 169-198.

Ergöçmen, B. A., Yüksel-Kaptanoğlu, İ., \& Jansen, H. A. (2013). Intimate partner violence and the relation between help-seeking behavior and the severity and frequency of physical violence among women in Turkey. Violence Against Women, 19(9), 1151-1174.

Erten, B., \& Keskin, P. (2020). Female employment and intimate partner violence: evidence from Syrian refugee inflows to Turkey. Journal of Development Economics, 150, 102607.

Gage, A. J. (2005). Women's experience of intimate partner violence in Haiti. Social Science \& Medicine, 61(2), 343-364.

Gaikwad, V., \& Rao, D. H. (2014). A cross-sectional study of domestic violence perpetrated by Intimate partner against married women in the reproductive age group in an urban slum area in Mumbai. Indian Journal of Public Health Research \& Development, 5(1), 49.

Geweke, J., Keane, M., \& Runkle, D. (1994). Alternative computational approaches to inference in the multinomial probit model. The Review of Economics And Statistics, 609-632.

Greene, W. H. (2012). Econometric analysis 4th edition. International Edition, New Jersey: Prentice Hall.

Guarnieri, E.; Rainer, H. (2018) : Female Empowerment and Male Backlash, CESifo Working Paper, No. 7009, Center for Economic Studies and ifo Institute (CESifo), Munich

Gul, S. S. (2013). The role of the state in protecting women against domestic violence and women's shelters in Turkey. In Women's Studies International Forum (Vol. 38, pp. 107-116). Pergamon.

Heath, R. (2014). Women's access to labor market opportunities, control of household resources, and domestic violence: Evidence from Bangladesh. World Development, 57, 32-46.

Jeyaseelan, L., Kumar, S., Neelakantan, N., Peedicayil, A., Pillai, R., \& Duvvury, N. (2007). Physical spousal violence against women in India: some risk factors. Journal of Biosocial Science, 39(5), 657.

Kandiyoti, D. (2016) Locating the politics of gender: Patriarchy, neoliberal governance and violence in Turkey. Research and Policy on Turkey, 1(2), 103-118, DOI:10.1080/23760818.2016.1201242 
Kerman T.K., \& Betrus, P. (2020). Violence against women in Turkey: A social ecological framework of determinants and prevention strategies. Trauma, Violence, \& Abuse, 21(3), 510-526.

Kishor, S., \& Johnson, K. (2004). Profiling domestic violence: a multi-country study. Studies in Family Planning, 36(3), 259-261.

Kizilgol, O. A., \& Ipek, E. (2018). An Analysis on Domestic Violence against Women in Turkey: Multinomial Logit Model. Business and Economics Research Journal, 9(3), 715-734.

Kocacık, F. \& Çağlayandereli, M., (2009). Domestic violence towards women: Denizli case study. Journal of Human Sciences, 6(2), 24-43.

Kocacık, F., Kutlar, A., \& Erselcan, F. (2007). Domestic violence against women: A field study in Turkey. The Social Science Journal, 44(4), 698-720.

La Mattina, G. (2017). Civil conflict, domestic violence and intra-household bargaining in post-genocide Rwanda. Journal of Development Economics, 124, 168-198.

McCulloch, R., \& Rossi, P. E. (1994). An exact likelihood analysis of the multinomial probit model. Journal of Econometrics, 64(1-2), 207-240.

Ministry of Family and Social Policies report of Turkey. (2014). Domestic Violence against Women in Turkey.

Muftuler-Bac, M., \& Muftuler, C. (2020). Provocation defence for femicide in Turkey: The interplay of legal argumentation and societal norms. European Journal of Women's Studies, 1(16)

Naved, R. T., \& Persson, L. A. (2005). Factors associated with spousal physical violence against women in Bangladesh. Studies in Family Planning, 36(4), 289-300.

Ogland, E. G., Xu, X., Bartkowski, J. P., \& Ogland, C. P. (2014). Intimate partner violence against married women in Uganda. Journal of Family Violence, 29(8), 869-879.

Official Gazette, (2021). Retrieved from: https://www.resmigazete.gov.tr/eskiler/2021/03/20210320-49.pdf

Özyurt, B. C., \& Deveci, A. (2010). Manisa'da kırsal bir bölgedeki 15-49 yaş evli kadınlarda depresif belirti yaygınlığı ve aile içi şiddetle ilişkisi. Türk Psikiyatri Dergisi, 21(1), 1-7.

Pal, S. (2019). Culture counters Male-Backlash: Causal evidence from India's Northeast. 
Paul, S. (2016). Women's labour force participation and domestic violence: Evidence from India. Journal of South Asian Development, 11(2), 224250.

Richardson, J. O., Coid, J., Petruckevitch, A., Chung, W. S., Moorey, S., \& Feder, G. (2002). Identifying domestic violence: cross sectional study in primary care. Bmj, 324(7332), 274.

Sahin, B., \& Dundar, P. E.(2017). Kadına yönelik şiddet ve yaşam kalitesi. Anatolian Journal of Psychiatry/Anadolu Psikiyatri Dergisi, 18(3).

TSI. (2014). The National Research on Domestic Violence Against Women in Turkey.

https://turkstatweb.tuik.gov.tr/Kitap.do?metod=KitapDetay\&KT_ID=11 \&KITAP_ID $=313$

Turkish Statistical Institute. (2021). Retrieved from: https://data.tuik.gov.tr/Bulten/Index?p=Labour-Force-Statistics-January2021-

37486\&dil=2\#: :text=The\%20number\%20of\%20persons\%20in,with\%2 01.2\%20percentage\%20point\%20increase.

Varisli, N. (2021). Türkiye'de Kadın İşgücünün Kayıt Dışı İstihdamdaki Durumu. The Journal of World Women Studies, 6(1).

Wahed, T., \& Bhuiya, A. (2007). Battered bodies \& shattered minds: Violence against women in Bangladesh. Indian Journal of Medical Research, 126(4), 341.

World Health Organization. (2013). Global and regional estimates of violence against women: prevalence and health effects of intimate partner violence and non-partner sexual violence. World Health Organization.

World Health Organization. (2021). Retrieved from https://apps.who.int/violence-info/intimate-partner-violence/

Yilmaz, O. (2017). Female autonomy, social norms and intimate partner violence against women in Turkey. The Journal of Development Studies, 54(8), 1321-1337.

Yount, K. M. (2005). Resources, family organization, and domestic violence against married women in Minya, Egypt. Journal of Marriage and Family, 67(3), 579-596. 